\title{
Direct Electrochemistry of Hemoglobin Immobilized in Polyvinylalcohol and Clay Composite Film Modified Carbon Ionic Liquid Electrode
}

\author{
Ni Hui, ${ }^{a}$ Rui-fang Gao, ${ }^{b}$ Xiao-qing Li, $^{b}$ Wei Sun ${ }^{* b}$ and Kui Jiao ${ }^{b}$ \\ ${ }^{a}$ College of Chemistry and Pharmacy, Qingdao Agriculture University, Qingdao 266109, P. R. China \\ ${ }^{b}$ Key Laboratory of Eco-chemical Engineering of Ministry of Education, College of Chemistry and Molecular \\ Engineering, Qingdao University of Science and Technology, Qingdao 266042, P. R. China
}

\begin{abstract}
Neste trabalho, líquido iônico hexaflúor-fosfato de 1-butil-3-metilimidazólio $\left(\mathrm{BMIMPF}_{6}\right)$, em temperatura ambiente, foi usado como ligante na fabricação de um eletrodo líquido iônico de carbono (CILE). Hemoglobina (Hb) foi imobilizada na superfície de CILE com argila e um filme composto por polivinil álcool (PVA) pelo método camada por camada. Espectros de UV-Vis e FT-IR mostraram que $\mathrm{Hb}$ no filme reteve as características essenciais de sua estrutura original. Experimentos eletroquímicos indicaram que um par de picos redox quase-reversíveis bem definidos foi obtido em solução tampão Britton-Robinson (B-R), pH 7,0. Os potenciais dos picos de oxidação e redução foram localizados em $-0,405 \mathrm{~V} \mathrm{e}-0,274 \mathrm{~V}$ ( vs. SCE), com potencial formal de $-0,340 \mathrm{~V}$, o qual contribuiu para a reação eletroquímica do par redox heme $\mathrm{Fe}(\mathrm{III}) / \mathrm{Fe}(\mathrm{II})$. Os resultados sugeriram que a tranferência de elétron direta de $\mathrm{Hb}$ no filme PVA/argila com CILE foi realizada. Os comportamentos eletroquímicos diretos de $\mathrm{Hb}$ foram estudados cuidadosamente com os parâmetros eletroquímicos calculados. O eletrodo CILE modificado, PVA/argila/Hb, apresentou excelente habilidade eletrocatalítica na redução de $\mathrm{H}_{2} \mathrm{O}_{2}$ e o valor para a constante de MichaelisMenten aparente, $\left(K_{M}{ }^{a p p}\right)$, de $\mathrm{Hb}$ no filme PVA/argila foi calculado como $56,26 \mu \mathrm{mol} \mathrm{L}^{-1}$.
\end{abstract}

In this paper room temperature ionic liquid 1-butyl-3-methylimidazolium hexafluorophosphate $\left(\mathrm{BMIMPF}_{6}\right)$ was used as binder to fabricate a carbon ionic liquid electrode (CILE). Hemoglobin $(\mathrm{Hb})$ was immobilized on the surface of CILE with clay and polyvinyl alcohol (PVA) composite film by layer to layer method. UV-Vis and FT-IR spectra showed that $\mathrm{Hb}$ in the film retained the essential features of its native structure. Electrochemical experiments indicated that a pair of well-defined quasi-reversible redox peak was obtained in $\mathrm{pH}$ 7.0 Britton-Robinson (B-R) buffer solution. The reduction and oxidation peak potentials were located at $-0.405 \mathrm{~V}$ and $-0.274 \mathrm{~V}$ (vs. SCE) with the formal potential as $-0.340 \mathrm{~V}$, which was contributed to the electrochemical reaction of heme $\mathrm{Fe}(\mathrm{III}) / \mathrm{Fe}(\mathrm{II})$ redox couples. The results suggested that the direct electron transfer of $\mathrm{Hb}$ in the PVA/Clay film with the CILE was accomplished. The direct electrochemical behaviors of $\mathrm{Hb}$ were carefully studied with the electrochemical parameters calculated. The PVA/ Clay/Hb modified CILE gave excellent electrocatalytic ability to the reduction of $\mathrm{H}_{2} \mathrm{O}_{2}$ and the apparent Michaelis-Menten constant $\left(K_{M}{ }^{a p p}\right)$ value of $\mathrm{Hb}$ in the PVA/Clay film was calculated as $56.26 \mu \mathrm{mol} \mathrm{L}-1$.

Keywords: hemoglobin, room temperature ionic liquid, carbon paste electrode, direct electrochemistry, 1-butyl-3-methylimidazolium hexafluorophosphate

\section{Introduction}

The studies on the relationships of structure and function of heme protein have intrigued researchers over the years. Hemoglobin $(\mathrm{Hb})$ is a member of heme protein and contains two $\alpha$ chains and two $\beta$ chains. ${ }^{1}$ While hemoglobin

*e-mail: sunwei@qust.edu.cn does not function physiologically as an electron transfer carrier, it does undergo oxidation and reduction at the heme center in certain cases in vivo. ${ }^{2}$ Therefore, the research on its electron transfer process might lead to a profound understanding of electron flow in biological systems. The direct electrochemistry of redox protein with the electrode had been extensively investigated in recent years. The research results could be used as a model to understand 
the electron transfer mechanism in biological system and apply to the fabrication of electrochemical biosensors or bioreactors. But the direct electron transfer of redox protein is difficult in the conventional electrode surface, so different kinds of films modified electrodes have been fabricated to provide a biocompatible microenvironment for protein to exchange the electron with the electrode..$^{3,4}$

Recently room temperature ionic liquids (RTILs) had been used in the protein electrochemistry. As a novel and attractive solvent, RTILs have many unique physicochemical properties such as high ionic conductivity, non-volatility, wide electrochemical windows and good solubility. RTILs are compounds composed entirely of the organic cations and various anions, and exist in liquid state around room temperature. They have been used in different fields such as electrochemistry, synthesis, biocatalysis and liquid-liquid extraction and so on..$^{5-8}$ Wei and Ivaska ${ }^{9}$ had reviewed the recent applications of RTILs in the electrochemical biosensors. Zhao et al. ${ }^{10}$ had investigated the electrical-ionic properties of RTILs/ carbon composite materials and further acted as modifiers in the direct electrochemistry of microperoxidase (MP-11). Lu et al. ${ }^{11}$ investigated the direct electrochemistry of hemoglobin $(\mathrm{Hb})$ in a composite system based on chitosan and 1-butyl-3-methylimidazolium tetrafluoroborate $\left(\mathrm{BMIMBF}_{4}\right)$. Yu et al. ${ }^{12}$ also applied a water-miscible imidazoliumbased ionic liquids film modified glassy carbon electrode for the direct electrochemistry of HRP. Rozniecka et al. ${ }^{13}$ demonstrated the effective ion transfer across RTIL/aqueous solution by using bulk modified electrode composed of carbon-nanotube based RTIL gel. ILs can also be used as a new kind of binder for carbon paste electrode. Maleki et al. ${ }^{14}$ fabricated a carbon composite electrode by using graphite powder mixed with n-octylpyridinum hexafluorophophate (OPFP) as binder. Sun et al. ${ }^{15}$ also combined N-butylpyridinium hexafluorophosphate (BPPF $\left.{ }_{6}\right)$ with graphite powder to make a new kind of carbon ionic liquid electrode (CILE). The RTILs modified electrodes were also used to detect different substances such as ascorbic acid, ${ }^{16}$ dopamine ${ }^{17}$ and nitric oxide. ${ }^{18}$

Hydrogen peroxide $\left(\mathrm{H}_{2} \mathrm{O}_{2}\right)$ plays important role in the fields of clinical test and biological chemistry. The oxidation of some biological substances in body can produce certain amounts of $\mathrm{H}_{2} \mathrm{O}_{2}$. The content of $\mathrm{H}_{2} \mathrm{O}_{2}$ is also related with the environmental chemistry. So it is of great importance to establish sensitive and convenient methods for $\mathrm{H}_{2} \mathrm{O}_{2}$ detection. In this paper a 1-butyl-3-methylimidazolium hexafluorophosphate $\left(\mathrm{BMIMPF}_{6}\right)$ modified carbon paste electrode was fabricated and $\mathrm{Hb}$ molecules were fixed on the surface of CILE with clay and polyvinyl alcohol (PVA). Hb can retain its bioactivity in the PVA/Clay organic-inorganic composite film and the direct electron transfer of $\mathrm{Hb}$ was achieved successfully in the modified electrode. The fabricated PVA/Clay/Hb/CILE showed good electrocatalytic ability to the reduction of $\mathrm{H}_{2} \mathrm{O}_{2}$.

\section{Experimental}

\section{Apparatus}

A CHI 750B electrochemical workstation (Shanghai $\mathrm{CH}$ Instrument, China) was used for all the electrochemical measurements. A traditional three-electrode system was used with a $\mathrm{Hb}$ modified CILE as working electrode, a platinum wire as auxiliary electrode and a saturated calomel electrode (SCE) as reference electrode. Voltammetry was carried out in $0.2 \mathrm{~mol} \mathrm{~L}^{-1}$ Britton-Robinson (B-R) buffer solution without hemoglobin. The buffers were purged with highly purified nitrogen for about $30 \mathrm{~min}$ prior to a series of experiments and a nitrogen environment was kept during the measurements. All the electrochemical experiments were performed at ambient temperature of $20 \pm 2{ }^{\circ} \mathrm{C}$. UV-Vis spectra were obtained on a Cary 50 probe UV-Vis spectrophotometer (Varian, Australia) and FT-IR spectra were on a Tensor 27 FT-IR spectrophotometer (Bruker, Germany).

\section{Chemicals}

Bovine hemoglobin (Hb, MW. 64500, Tianjin Chuanye Biochemical Limited Company), the ionic liquid of 1-butyl3-methylimidazolium hexafluorophosphate (BMIMPF${ }_{6}$, Hangzhou Kemer Chemical Limited Company), clay (Zhejiang Zhedi Nonmetal Limited Company) and polyvinyl alcohol (PVA, Tianjin Bodi Chemical Limited Company) were used as received. $0.2 \mathrm{~mol} \mathrm{~L}^{-1}$ BrittonRobinson (B-R) buffers of various $\mathrm{pH}$ values were used as the supporting electrolyte. All the other chemicals were of analytical reagent grade and double-distilled water was used in all experiments.

\section{Preparation of PVA/Clay/Hb/CILE}

Ionic liquid modified carbon paste electrode (CILE) was prepared according to the reference. ${ }^{19}$ Generally speaking, $0.8 \mathrm{~mL}$ of $\mathrm{BMIMPF}_{6}$ and $3.2 \mathrm{~g}$ of graphite powder were hand-mixed in an agate mortar and ground carefully. A portion of resulting homogeneous paste was packed firmly into a glass tube cavity $\left(\mathrm{A}=0.12 \mathrm{~cm}^{2}\right)$. The electric contact was established through a copper wire to the end of the paste in the inner hole of the tube. The surface of CILE was polished by smoothing on a weighing paper. Then 
CILE was used as the working electrode for the following modification.

$\mathrm{Hb}$ modified CILE was prepared in the following procedure. $10 \mu \mathrm{L}$ of $15.0 \mathrm{mg} \mathrm{mL}^{-1} \mathrm{Hb}$ solution (in $\mathrm{pH} 7.5$ B-R buffer) was dropped onto the smoothed CILE surface and spread gently over the entire surface. The electrode was left in the air to dry under ambient conditions for about $6 \mathrm{~h}$. A small bottle was fit tightly over the electrode so that water was evaporated gradually and one uniform film can be achieved. Then $10 \mu \mathrm{L}$ of the $4.0 \mathrm{mg} \mathrm{mL}^{-1}$ clay suspension solution was pipetted to cover the $\mathrm{Hb}$-modified CILE and dried at room temperature. Finally, $10 \mu \mathrm{L}$ of the $2.0 \mathrm{mg} \mathrm{mL}^{-1}$ PVA solution was spread onto dry clay film surface. Then the preparation of the modified electrode was finished and it was denoted as PVA/Clay/Hb/CILE. The resulted $\mathrm{Hb}$ modified electrode was stored at $4{ }^{\circ} \mathrm{C}$ when it was not in use. The PVA/Clay/CILE was prepared in the same procedure just without the addition of $\mathrm{Hb}$.

\section{Results and Discussion}

\section{Electrochemical behaviors of PVA/Clay/Hb/CILE}

The electrochemical behaviors of entrapped $\mathrm{Hb}$ molecules were examined by cyclic voltammetry and the results were shown in Figure 1. A pair of well-defined quasireversible redox peaks appeared with the Epa $=-0.274 \mathrm{~V}$ and $\mathrm{Epc}=-0.405 \mathrm{~V}(v s . \mathrm{SCE})$ and the ratio of $\mathrm{Ipa} / \mathrm{Ipc}=$ 0.993. The formal potential $\left(\mathrm{E}^{0}\right)$, which is calculated by the midpoint of Epa and Epc, was got as $-0.340 \mathrm{~V}$ ( $v s$. $\mathrm{SCE})$ and the peak-to-peak separation $(\Delta \mathrm{Ep})$ was got as $131 \mathrm{mV}$ at the scan rate of $100 \mathrm{mV} \mathrm{s}^{-1}$, which indicated a fast heterogeneous electron transfer process..$^{20-23}$ The results

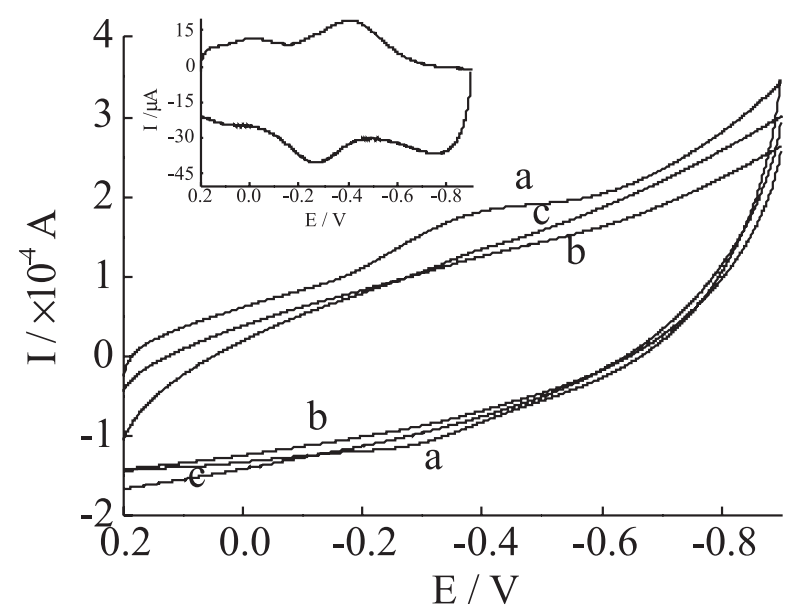

Figure 1. Cyclic voltammograms of (a) PVA/Clay/Hb/CILE, (b) PVA/ Clay/CILE and (c) bare CILE in pH 7.0 B-R buffer at the scan rate of $100 \mathrm{mV} \mathrm{s}^{-1}$ (inset: the background-subtracted cyclic voltammogram of $\mathrm{PVA} / \mathrm{Clay} / \mathrm{Hb} / \mathrm{CILE}$ using data presented in curve b). are in good agreement with the characteristics of the heme $\mathrm{Fe}(\mathrm{III}) / \mathrm{Fe}$ (II) redox couples. While no voltammetric peak appeared at bare CILE or PVA/Clay/CILE. These results indicated that the PVA/Clay organic-inorganic hybrid membranes provided a suitable microenvironment for the $\mathrm{Hb}$ molecules and the presence of IL in the electrode could enhance the electron transfer rate for $\mathrm{Hb}$. Then the direct electron transfer of $\mathrm{Hb}$ in the PVA/Clay film was achieved successfully.

\section{Effect of the scan rate}

The relationships of the anodic and cathodic peak currents with the scan rate were investigated in the range of 50 to $200 \mathrm{mV} \mathrm{s}^{-1}$ and the results were shown in Figure 2 (A). Both the redox peak currents increased with the scan rate and two linear plots could be obtained, which was the typical behaviors of surface-confined thin-layer electrochemistry. The results suggested that all the electroactive $\mathrm{Hb} \mathrm{Fe}(\mathrm{III})$ in the film was converted to $\mathrm{Hb} \mathrm{Fe}$ (II) on the forward cyclic voltammetric scan and then transferred back to $\mathrm{Hb} F$ (III) on the reverse scan. For a thin-layer electrochemistry the surface coverage was estimated by the integration of the redox peak current according to the equation: $\mathrm{Q}=\mathrm{nFA} \Gamma^{*}$, where $\mathrm{Q}$ is charge passing through the electrode with full reduction of electroactive $\mathrm{Hb}$ in the film, $\mathrm{A}$ is the geometric area of the CILE, $\mathrm{n}$ and $\mathrm{F}$ have their usual meaning, $\Gamma^{*}$ is the surface concentration of the electroactive substance. The charge values were nearly constant in different scan rates and the average value of $\Gamma^{*}$ was calculated as $8.67 \times 10^{-9} \mathrm{~mol} \mathrm{~cm}^{-2}$. Thus the fraction of electroactive $\mathrm{Hb}$ in the film was estimated as about $44.7 \%$.

In the scan rate from 50 to $200 \mathrm{mV} \mathrm{s}^{-1}$, all the electrochemical response of $\mathrm{Hb}$ showed a quasi-reversible process. With the increase of the scan rate, the reduction peak moved negatively and the oxidation peak moved positively, and the value of $\Delta \mathrm{E}$ was less than $200 \mathrm{mV}$. According to the Laviron's equation for quasi-reversible thin-layer electrochemistry when the $\mathrm{n} \times \Delta \mathrm{E}<200 \mathrm{mV}$, the apparent heterogeneous electron transfer rate constant $(k s)$ can be calculated with the following equations: ${ }^{24}$

$$
\begin{aligned}
& E p c=E^{0^{\prime}}-\frac{2.3 R T}{\alpha n F} \log v \\
& E p a=E^{0^{\prime}}+\frac{2.3 R T}{(1-\alpha) n F} \log v \\
& \log k_{s}=\alpha \log (1-\alpha)+(1-\alpha) \log \alpha- \\
& \log \frac{R T}{n F v}-\frac{n F \Delta E p \alpha(1-\alpha)}{2.3 R T}
\end{aligned}
$$


where $\alpha$ is the charge transfer coefficient, $\mathrm{n}$ is the number of electron transfer and $\mathrm{v}$ is the scan rate. The relationships of Ep with $\log v$ were calculated and shown in Figure 2 (B) with two linear equations got. Form the slope and the intercept the value of $\mathrm{n}$ and $\alpha$ were got as 0.99 and 0.36 , respectively. From the equation 3, the value of $k s$ was calculated as $0.54 \mathrm{~s}^{-1}$, which was also proved as a quasireversible redox process of $\mathrm{Hb}$.
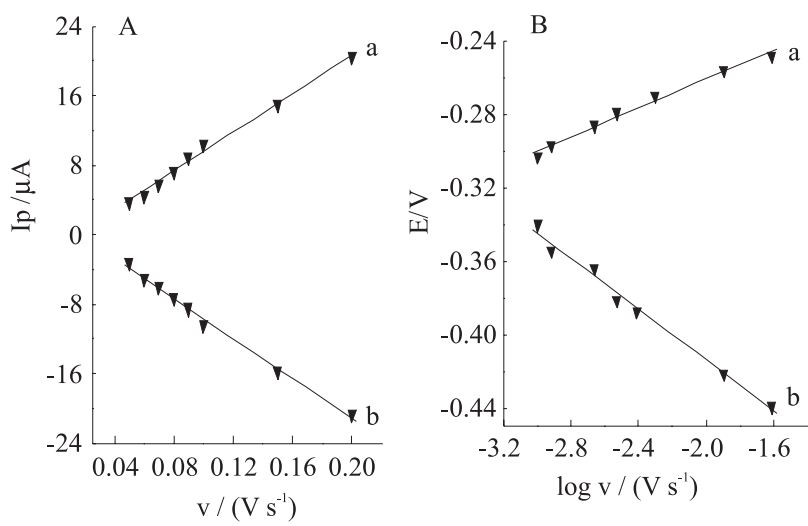

Figure 2. (A) Linear relationships of the Ipc (a) and Ipa (b) versus scan rate $(v)$ and (B) linear relationships of Epa (a) and Epc (b) versus log $v$ for PVA/Clay/Hb/CILE in pH 7.0 B-R buffer.

\section{Effect of the buffer $p H$}

In most cases the redox behaviors of $\mathrm{Hb}$ are often greatly dependent on the solution $\mathrm{pH}$. With the increase of the $\mathrm{pH}$ value of buffer solution a negative shift of both the redox peak potentials of $\mathrm{Hb}$ appeared. The formal potential $\left(\mathrm{E}^{0^{\prime}}\right)$ showed a good linear function with the buffer $\mathrm{pH}$ in the range of 3.0-9.0 (Figure 3). The slope value was calculated as $-41.05 \mathrm{mV} \mathrm{pH}^{-1}$, which was smaller than the theoretical value of $-56 \mathrm{mV} \mathrm{pH}{ }^{-1}\left(20{ }^{\circ} \mathrm{C}\right)$ for reversible one proton-coupled one electron transfer process. But the linear relationship between the $\mathrm{E}^{0}$ and the $\mathrm{pH}$ also suggested that the one electron transfer between the electrode and the protein was accompanied by one proton transfer. The electrode reaction equation could be simplified as:

$\mathrm{Hb}$ heme $\mathrm{Fe}(\mathrm{III})+\mathrm{H}^{+}+\mathrm{e}^{-} \rightleftharpoons$ Hb heme Fe(II)

where the charges on $\mathrm{Hb}$ species were omitted.

\section{Stability of the modified electrode}

The stability of the modified electrode was also examined. After the PVA/Clay/Hb/CILE was stored at $4{ }^{\circ} \mathrm{C}$ for one week, only $2.1 \%$ decrease in the current response was observed. After a 30 days storage period,

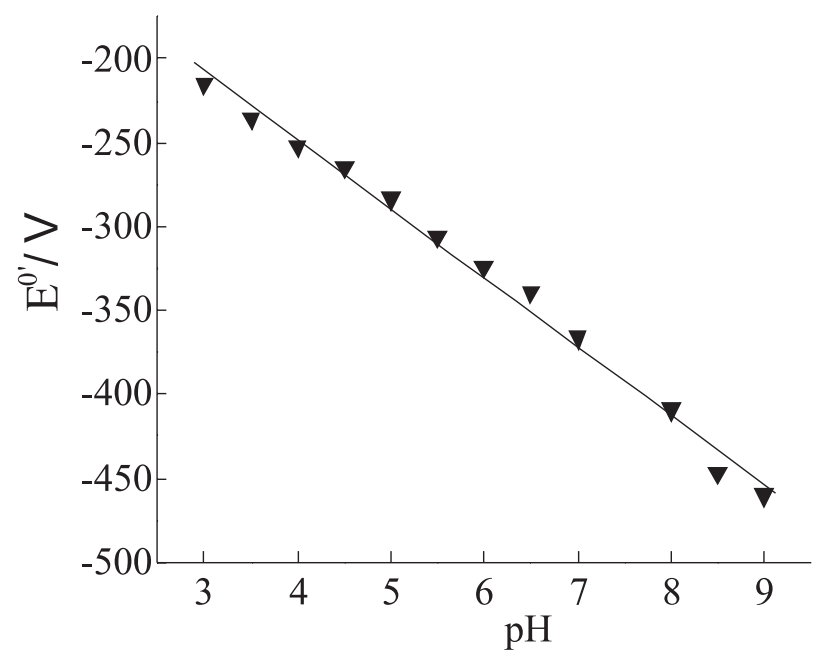

Figure 3. The relationship between the formal potential $\left(\mathrm{E}^{0^{\prime}}\right)$ and $\mathrm{pH}$ of buffer solution.

the modified electrode retained $91.4 \%$ of its initial current response, which indicated that the PVA/Clay/Hb film had good stability.

\section{Electrocatalytic activity to $\mathrm{H}_{2} \mathrm{O}_{2}$}

The electrocatalytic activity of $\mathrm{Hb}$ incorporated in the PVA/Clay film to the reduction of $\mathrm{H}_{2} \mathrm{O}_{2}$ was further investigated with the cyclic voltammograms shown in Figure 4. $\mathrm{Hb}$ is a mimic peroxidase with the similar active structure as peroxidase and showed peroxidase activity. When the different amounts of $\mathrm{H}_{2} \mathrm{O}_{2}$ were added into a $\mathrm{pH}$ 7.0 B-R buffer solution, a new reduction peak at about $-0.264 \mathrm{~V}$ was observed with the disappearance of the oxidation peak. The phenomena were the characteristics of an electrochemically catalytic reaction. While no similar results can be got at either bare CILE or PVA/Clay/CILE in the same $\mathrm{H}_{2} \mathrm{O}_{2}$ solution. So the $\mathrm{Hb}$ present in the film can greatly decrease the activation energy for the reduction of $\mathrm{H}_{2} \mathrm{O}_{2}$. The more the $\mathrm{H}_{2} \mathrm{O}_{2}$ added, the greater the reduction peak current increased. By using cyclic voltammetry the catalytic reduction peak current had a good linear relationship with the concentration of $\mathrm{H}_{2} \mathrm{O}_{2}$ in the range from $7.5 \times 10^{-6}$ to $1.0 \times 10^{-4} \mathrm{~mol} \mathrm{~L}^{-1}$. The linear regression equation was got as

$\operatorname{Iss}(\mu \mathrm{A})=0.34 \mathrm{C}(\mu \mathrm{mol} \mathrm{L}-1)+6.42(\mathrm{n}=20, \gamma=0.997)$

with the detection limit as $2.0 \times 10^{-6} \mathrm{~mol} \mathrm{~L}^{-1}(3 \sigma)$. When the $\mathrm{H}_{2} \mathrm{O}_{2}$ concentration was more than $1.0 \times 10^{-4} \mathrm{~mol} \mathrm{~L}^{-1}$, the curve leveled off, which was in consistent with the enzyme catalytic kinetic mechanism of the substrate. According to the references, ${ }^{25,26}$ the possible catalytic mechanism by PVA/ Clay/Hb/CILE is postulated as following: 


$$
\begin{aligned}
& \mathrm{HbFe}(\mathrm{III})+\mathrm{H}_{2} \mathrm{O}_{2} \rightarrow \text { Compound } \mathrm{I}+\mathrm{H}_{2} \mathrm{O} \\
& \text { Compound I }+\mathrm{H}_{2} \mathrm{O}_{2} \rightarrow \mathrm{HbFe}(\mathrm{III})+\mathrm{O}_{2}+\mathrm{H}_{2} \mathrm{O} \\
& \mathrm{HbFe}(\mathrm{III})+\mathrm{H}^{+}+\mathrm{e}^{-} \rightarrow \mathrm{HbFe}(\mathrm{II}) \text { (at electrode) } \\
& \mathrm{HbFe}(\mathrm{II})+\mathrm{O}_{2} \rightarrow \mathrm{HbFe}(\mathrm{II})-\mathrm{O}_{2} \text { (fast) } \\
& \mathrm{HbFe}(\mathrm{II})-\mathrm{O}_{2}+2 \mathrm{H}^{+}+2 \mathrm{e}^{-} \rightarrow \mathrm{HbFe}(\mathrm{II})+\mathrm{H}_{2} \mathrm{O}_{2} \\
& \quad \text { (at electrode) }
\end{aligned}
$$

There are two catalytic cycles here: $\mathrm{Hb} F($ II) reacts with $\mathrm{O}_{2}$ and forms $\mathrm{Hb} \mathrm{Fe}$ (II)- $\mathrm{O}_{2}$ in equation 9, the produced $\mathrm{Hb} \mathrm{Fe}(\mathrm{II})-\mathrm{O}_{2}$ will receive two electrons at electrodes and return to $\mathrm{Hb} \mathrm{Fe}(\mathrm{II})$ again in equation 10 . The $\mathrm{H}_{2} \mathrm{O}_{2}$ produced in equation 10 will then induce or promote the catalytic cycle of equation 9 and 10.

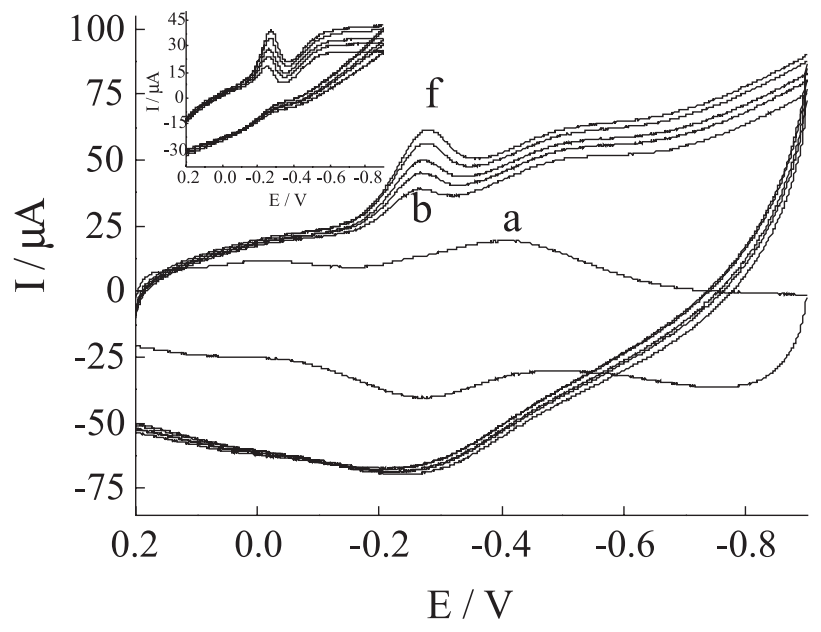

Figure 4. Cyclic voltammograms of PVA/Clay/Hb/CILE with different amounts of $\mathrm{H}_{2} \mathrm{O}_{2}$ (a-f: $0,20.0,22.5,25.0,27.5,30.0 \mu \mathrm{mol} \mathrm{L}^{-1} \mathrm{H}_{2} \mathrm{O}_{2}$ ), respectively. Scan rate: $100 \mathrm{mV} \mathrm{s}^{-1}$ (inset: the background-subtracted cyclic voltammograms from $b$ to $f$ using data presented in curve a).

The apparent Michaelis-Menten constant $\left(\mathrm{K}_{\mathrm{M}}{ }^{\text {app }}\right)$, which indicates the kinetics of enzyme-substrate reaction, is calculated according to the electrochemical version of the Lineweaver-Burk equation: ${ }^{27}$

$\frac{11}{I_{S S}}=\frac{}{I_{\max }}+\frac{K_{M}^{a p p}}{I_{\max } C}$

where $I_{s s}$ is the steady-state current after the addition of substrate, $\mathrm{C}$ is the bulk concentration of the substrate, $I_{\max }$ is the maximum current measured at the saturated substrate conditions. According to the relationship of $1 / \mathrm{I}_{\mathrm{ss}}$ and $1 / \mathrm{C}$, the $\mathrm{K}_{\mathrm{M}}{ }^{\text {app }}$ value of $\mathrm{Hb}$ in the PVA/Clay film was calculated to be $56.26 \mu \mathrm{mol} \mathrm{L}^{-1}$, which was smaller than some reported values. ${ }^{28-33}$ Because the small $\mathrm{K}_{\mathrm{M}}$ app value represents the higher catalytic ability, so the entrapped $\mathrm{Hb}$ in the PVA/Clay film showed higher sensitivity to $\mathrm{H}_{2} \mathrm{O}_{2}$. The proposed $\mathrm{H}_{2} \mathrm{O}_{2}$ biosensor was compared with other $\mathrm{Hb}$ modified electrodes with the results listed in Table 1. It could be seen that this method provided comparable linear range and detection limit. The results also indicated that different films modified electrode provided different microenvironments for $\mathrm{Hb}$ immobilization.

The possible interferences from foreign substances on the determination of $1.0 \times 10^{-5} \mathrm{~mol} \mathrm{~L}^{-1} \mathrm{H}_{2} \mathrm{O}_{2}$ were investigated by the proposed biosensor. No significant interference can be observed for common ions including $\mathrm{Na}^{+}, \mathrm{K}^{+}, \mathrm{Ca}^{+}, \mathrm{CO}_{3}{ }^{2+}, \mathrm{PO}_{4}{ }^{3-}, \mathrm{SO}_{4}{ }^{2-}, \mathrm{Cl}^{-}$at the concentrations of 10-fold higher than that of $\mathrm{H}_{2} \mathrm{O}_{2}$. The results indicated that the $\mathrm{H}_{2} \mathrm{O}_{2}$ biosensors exhibited a good selectivity.

\section{Spectroscopic results}

UV-Vis and FT-IR spectroscopy were used to compare the structural information of $\mathrm{Hb}$ in the film. UV-Vis absorption spectra can give structural information about the environmental surroundings of the heme group of $\mathrm{Hb}$. As shown in Figure 5, native $\mathrm{Hb}$ had its Soret band at $404.68 \mathrm{~nm}$ in $\mathrm{pH} 7.0$ buffer solution (curve a), which would shift or disappear if the protein structure had been

Table 1. Comparison of different $\mathrm{Hb}$ modified electrodes for $\mathrm{H}_{2} \mathrm{O}_{2}$ determination

\begin{tabular}{lcccc}
\hline Electrode & Linear range $/\left(\mu \mathrm{mol} \mathrm{L}^{-1}\right)$ & Limit of detection $/\left(\mu \mathrm{mol} \mathrm{L}^{-1}\right)$ & $\mathrm{K}_{\mathrm{M}}^{\text {app }} /\left(\mathrm{mmol} \mathrm{L}^{-1}\right)$ & References \\
\hline Sol-gel-HRP-CPE & $0.2-2600$ & - & 4.8 & 28 \\
HRP/kieselguhr/PVA/PG & $2.4-650$ & 1.0 & 572 & 29 \\
$\mathrm{Hb}-$ Nafion-Co $\mathrm{O}_{4}$-GC & $1-390$ & 0.1 & 0.136 & 30 \\
$\mathrm{Hb} / \mathrm{ATP} / \mathrm{GC}$ & $5.4-400$ & 2.4 & 0.49 & 31 \\
$\mathrm{Hb}-$ sol-gel-CPE & $5.0-700$ & - & 0.898 & 32 \\
$\mathrm{Hb} / \mathrm{ZrO} /$ DMSO/PG & $1.5-30.2$ & 0.14 & 0.31 & 33 \\
PVA/Clay/Hb/CILE & $7.5-100$ & 2.0 & 0.05626 & This paper \\
\hline
\end{tabular}

Hb: hemoglobin; ATP: attapulgite; DMSO: dimethyl sulfoxide; PG: pyrolytic graphite; PVA: polyvinyl alcohol. 


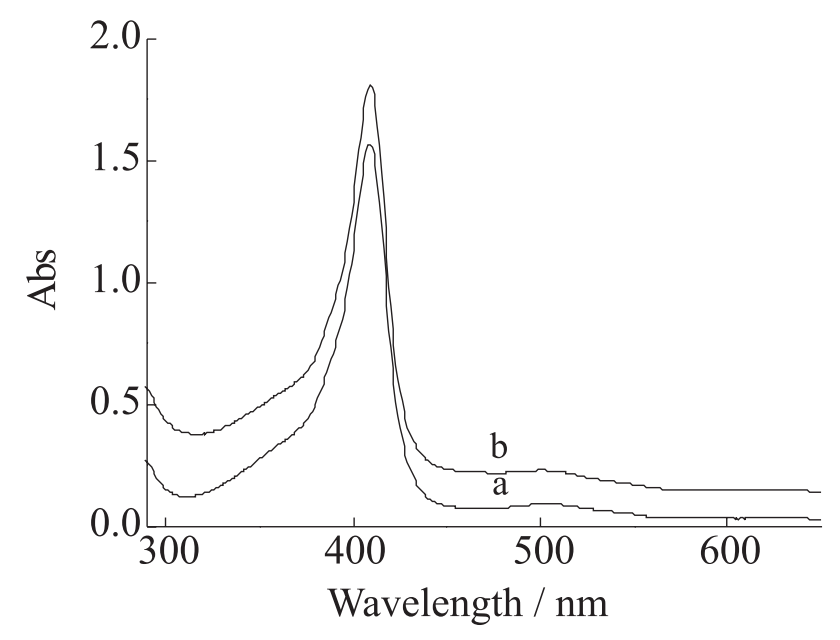

Figure 5. UV-Vis absorption spectra of $\mathrm{Hb}$ in $\mathrm{pH}$ 7.0 B-R buffer (a) and its mixture with PVA/Clay (b).

changed or the protein was denatured. After the mixture of Hb with PVA/Clay solution, the Soret band appeared at $404.87 \mathrm{~nm}$ (curve b) with only $0.19 \mathrm{~nm}$ shifted. The results indicated that $\mathrm{Hb}$ in the PVA/Clay film was not distinctly denatured and its secondary structure was kept as the native state of $\mathrm{Hb}$. Since PVA/Clay can provide a compatible microenvironment for heme groups of $\mathrm{Hb}$ and keep its native structure, so PVA/Clay composite material might be a fine film material for the direct electrochemistry of $\mathrm{Hb}$.

FT-IR spectroscopy is a sensitive probe for secondary structure of proteins. The shape and position of amide I $\left(1600-1700 \mathrm{~cm}^{-1}\right)$ and amide II $\left(1500-1600 \mathrm{~cm}^{-1}\right)$ of IR bands provide detailed information on the secondary structure of the polypeptide chain. ${ }^{34,35}$ The amide I band at $1700-1600 \mathrm{~cm}^{-1}$ is caused by $\mathrm{C}=\mathrm{O}$ stretching vibrations of the peptide linkage. The amide II band at $1600-1500 \mathrm{~cm}^{-1}$ results from a combination of $\mathrm{N}-\mathrm{H}$ in-plane bending and $\mathrm{C}-\mathrm{N}$ stretching of the peptide groups. If $\mathrm{Hb}$ is denatured, the intensities of the amide I and II bands will significantly diminish or even disappear. As shown in Figure 6, the

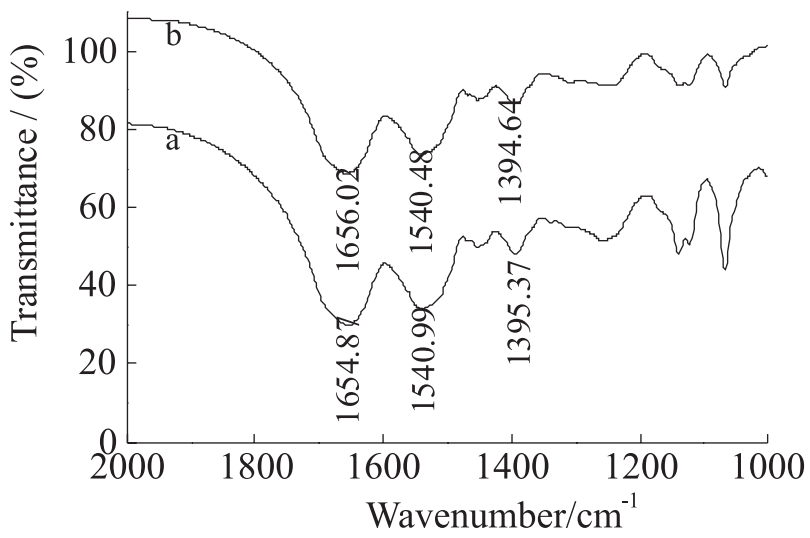

Figure 6. FT-IR spectra of (a) $\mathrm{Hb}$ and (b) PVA/Clay/Hb film. spectra of amide I and II bands of $\mathrm{Hb}$ in the PVA/Clay film (1656.02 and $\left.1540.48 \mathrm{~cm}^{-1}\right)$ were nearly the same as that of nature $\mathrm{Hb}\left(1654.87\right.$ and $\left.1540.99 \mathrm{~cm}^{-1}\right)$. The similarities of FT-IR spectra indicated that the $\mathrm{Hb}$ in the PVA/Clay composite film remained its native structure, so it could exhibit excellent direct electrochemistry and electrocatalytic behaviors.

\section{Conclusions}

In this paper a $\mathrm{BMIMPF}_{6}$ modified carbon paste electrode was used as a new basal electrode for $\mathrm{Hb}$ immobilization. A PVA/Clay organic-inorganic composite film was used to entrap the $\mathrm{Hb}$ molecules on the surface of CILE. UV-Vis and FT-IR spectra indicated that $\mathrm{Hb}$ retained its native structure in the film. The direct electron transfer of $\mathrm{Hb}$ in the PVA/Clay film with CILE was achieved and the electrochemical behaviors of $\mathrm{Hb}$ were carefully investigated. The entrapped $\mathrm{Hb}$ exhibited good catalytic activity towards $\mathrm{H}_{2} \mathrm{O}_{2}$, which showed the potential for the third-generation electrochemical biosensor.

\section{Acknowledgments}

We are grateful for the financial support of the National Science Foundation of China (No. 20635020, 20405008).

\section{References}

1. Perutz, M. F.; Wilkinson, A. J.; Paoli, M.; Dodson, G. G.; Annu. Rev. Biophys. Biomol. Struct. 1998, 27, 1.

2. Schumacher, M. A.; Dixon, M. M.; Kluger, R.; Jones, R. T.; Brennan, R.G.; Nature 1995, 375, 84.

3. Armstrong, F. A.; Hill, H. A. O.; Walton, N. J.; Acc. Chem. Res. 1988, 21, 407.

4. Rusling, J. F.; Acc. Chem. Res. 1998, 31, 363.

5. Buzzeo, M. C.; Hardace, C.; Compton, R. G.; Anal. Chem. 2004, 76, 4583.

6. Hiroyuki, O.; Electrochemical Aspects of Ionic Liquids, John Wiley \& Sons Inc: New York, 2005.

7. Buzzo, M. C.; Evans, R. G.; Comoton, R. G.; Chem. Phys. Chem. 2004, 5, 1106.

8. Sun, H.; J. Porous Mater. 2006, 13, 393.

9. Wei, D.; Ivaska, A.; Anal. Chim. Acta 2008, 607, 126.

10. Zhao, F.; Wu, X. M.; Wang, M. K.; Liu, Y.; Gao, L.; Dong, S. J.; Anal. Chem. 2004, 76, 4960.

11. Lu, X. B.; Zhang, Q.; Zhang, L.; Li, J. H.; Electrochem. Commun. 2006, 8, 874.

12. Yu, P.; Lin, Y. Q.; Xiang, L.; Lei, S.; Zhang, J.; Mao, L. Q.; Langmuir 2005, 21, 9000. 
13. Rozniecka, E.; Niedziolka, J.; Sirieix-Plenet, J.; Gaillon, L.; Murphy, M. A.; Marken, F.; Opallo, M.; J. Electroanal. Chem. 2006, 587, 133.

14. Maleki, N.; Safavi, A.; Tajabadi, F.; Anal. Chem. 2006, 78, 3820.

15. Sun, W.; Gao, R. F.; Bi, R. F.; Jiao, K.; Chin. J. Anal. Chem. 2007, 35, 367

16. Yan, Q. P.; Zhao, F. Q.; Li, G. Z.; Zeng, B. Z.; Electroanalysis 2006, 18, 1075 .

17. Zhao, Y. F.; Gao, Y. Q.; Zhan, D. P.; Liu, H.; Zhao, Q.; Kou, Y.; Shao, Y. H.; Li, M. X.; Zhang, W. K.; Zhu, Z. W.; Talanta 2005, 66, 51.

18. Li, C. M.; Zang, J. F.; Zhan, D. P.; Chen, W.; Sun, C. Q.; Teo, A. L.; Chua, Y. T.; Lee, V. S.; Moochhala, S. M.; Electroanalysis 2006, 18, 713 .

19. Sun, W.; Gao, R. F.; Jiao, K.; Electroanalysis 2007, 19, 1368.

20. Liu, X. J.; Xu, Y.; Ma, X.; Li, G. X.; Sens. Actuators, B 2005, 106, 284.

21. Shang, L.; Liu, X.; Zhong, J.; Fan, C.; Suzuki, I.; Li, G.; Chem. Lett. 2003, 32, 296.

22. Fan, C.; Wang, H.; Sun, S.; Zhu, D.; Wagner, G.; Li, G.; Anal. Chem. 2001, 73, 2850.

23. Liu, H.; Hu, N.; Anal. Chim. Acta 2003, 481, 91.
24. Laviron, E.; J. Electroanal. Chem. 1979, 101, 19.

25 He, P. L.; Hu, N. F.; Zhou, G.; Biomacromolecules 2002, 3, 139.

26. Gorton, L.; Jonsson-Pettersson, G.; Csoregi, E.; Johansson, K.; Dominguez, E.; Marko-Varga, G.; Analyst 1992, 117, 1235.

27. Sun, W.; Gao, R. F.; Jiao, K.; J. Phys. Chem. B 2007, 111, 4560 .

28. Li, J.; Tan, S. N.; Ge, H. L.; Anal. Chim. Acta 1996, 335, 137.

29. Fan, C. H; Wang, H. Y; Zhu, D.; Wagner, G.; Li, G. X; Anal. Sci. 2001, 17, 273.

30. Lu, X.B.; Zou, G. F.; Li, J. H.; J. Mater. Chem. 2007, 17, 1427.

31. Xu, J. M.; Li, W.; Yin, Q. F.; Zhang, H.; Zhu, Y. L.; Jin, L. T.; J. Colloid Interface Sci. 2007, 35, 170.

32. Wang, Q. L.; Lu, G. X.; Yang, B. J.; Biosens. Bioelectron. 2004, $19,1269$.

33. Liu, S. Q.; Dai, Z. H.; Chen, H. Y.; Ju, H. X.; Biosens. Bioelectron. 2004, 19, 963.

34. Kauppinen, J. K.; Moffat, D. J.; Mantsch, H. H.; Cameron, D. G.; Appl. Spectrosc. 1981, 35, 271.

35. Rusling, J. F.; Kumonsinski, T. F.; Intell. Instrum. Comput. 1992, 10, 139. 